\title{
There is no association between the presence of anti-thyroid antibodies and increased reproductive loss in pregnant women after ART: a systematic review and meta-analysis
}

\author{
Paz Leiva1 ${ }^{1}$ Juan Enrique Schwarze ${ }^{1,2}$, Pamela Vasquez ${ }^{3}$, Carolina Ortega², Sonia Villa ${ }^{2}$, Javier Crosby ${ }^{4}$, José $^{2}$ \\ Balmaceda², Ricardo Pommer² \\ ${ }^{1}$ Obstetrics and Gynecology Department at Universidad de Santiago, Chile \\ ${ }^{2}$ Reproductive Medicine Unit at Clinica Monteblanco \\ ${ }^{3}$ Epidemiology Department, Universidad de los Andes \\ ${ }^{4}$ Reproductive Medicine Unit at Clinica Las Condes
}

\begin{abstract}
Women submitted to ART treatments represent a select subgroup of individuals. Several studies have described the relationship between TAI and pregnancy outcomes as a result of ART, with contradictory results. The purpose of this systematic review was to determine the association between TAI and the risk of miscarriage in pregnancies resulting from ART. MEDLINE via PubMed, LILACS and Embase were searched for studies published in peerreviewed journals from 1999 to 2017. The studies were summarized using the fixed effects model and the Peto's method to calculate RR in order to flesh out the association between TAI and spontaneous abortion. Only four papers were included in this systematic review and meta-analysis. Thirty-one miscarriages were observed in 210 clinical pregnancies of women with antithyroid antibodies; and 158 miscarriages were seen in 1,371 pregnancies without antithyroid antibodies. The meta-analysis failed to find an association between TAI and higher risk of reproductive loss, $\mathrm{RR}=0.9495 \%$ confidence interval: $0.71-1.24 ; p=0.879$. In conclusion, the presence of antithyroid antibodies was not associated with increased reproductive loss in patients submitted to ART treatments. It is our opinion that the presence of antithyroid antibodies should be considered as a secondary biomarker of autoimmune disease, rather than an actual cause of miscarriage in patients undergoing ART. Due to the small amount of evidence on the matter, the determination of TAI before the initiation of ART should be limited to research contexts.
\end{abstract}

Keywords: ART, anitbodies, thyroid

\section{INTRODUCTION}

The percentage of women in the general population with thyroid autoimmunity (TAI), whether by thyroglobulin autoantibodies (anti-Tg) or anti-thyroid peroxidase antibodies (TPOAb), may be as high as $20 \%$ (Davies, 2016; Łukaszuk et al., 2015). In 1930, Stagnaro-Green et al. (1990) described the association between TAI and risk of spontaneous abortion. Since then, increased risk of fetal loss, perinatal mortality, and large for gestational age (LGA) newborns have been reported for euthyroid women with elevated concentrations of TPOAb (Bussen \& Steck, 1995; Prummel \& Wiersinga, 2004; Männistö et al. 2009). Other studies suggested that the presence of TAI in euthyroid women was associated with a 2-3 fold higher risk of miscarriage (Chen \& Hu, 2011; Thangaratinam et al., 2011). The causality and pathophysiology of this association, or the adequate course of treatment, have not been completely elucidated.
Women submitted to assisted reproductive technology (ART) treatments represent a select subgroup of individuals. Several studies have described the relationship between TAI and pregnancy outcomes as a result of ART, with contradictory results (Abalovich et al., 2007; StagnaroGreen \& Glinoer, 2004). The purpose of this systematic review was to determine the association between TAI and the risk of miscarriage in pregnancies resulting from ART.

\section{MATERIALS AND METHODS}

\section{Electronic search}

MEDLINE via PubMed, LILACS and Embase were searched for papers written in English and Spanish published in peer-reviewed journals from 1999 to 2017. Search terms "antithyroid antibodies" "assisted reproductive techniques", and the combined MeSH terms "reproductive techniques, assisted OR fertilization in vitro OR sperm injections, intracytoplasmic" AND "thyroid gland" AND "autoantibodies" were used. Additional studies were found in the references of the retrieved papers.

\section{Study selection}

Studies looking into ART in women with ages ranging from 22 to 45 years were eligible for inclusion in the review. Secondary studies, studies without comparable groups, and studies performing Preimplantation Genetic Diagnosis were excluded.

The papers were selected based on their titles and abstracts according to the inclusion criteria (Figure 1).

\section{Selected outcomes}

Papers comparing the pregnancy outcomes of individuals with and without TAI offered ART treatments were included, whereas studies not reporting pregnancy outcomes were not included (e.g. birth or miscarriage).

\section{Data extraction}

Two independent authors reviewed the titles and abstracts (PL and JES), and when applicable the full text was retrieved for further analysis. The independent authors assessed the papers for compliance with the inclusion criteria. Disagreements were resolved with the aid of a third author (CO). Data was extracted by one of the authors (PL) in a specially designed form that included references, study type, methods, results, and conclusions.

\section{Methods of synthesis}

The studies were summarized using the fixed effects model and Peto 's method to calculate relative risk (RR) and $95 \%$ confidence intervals to further elicit the association between TAI and spontaneous abortion in women offered ART. Statistical analysis was performed on STATA 11.0 


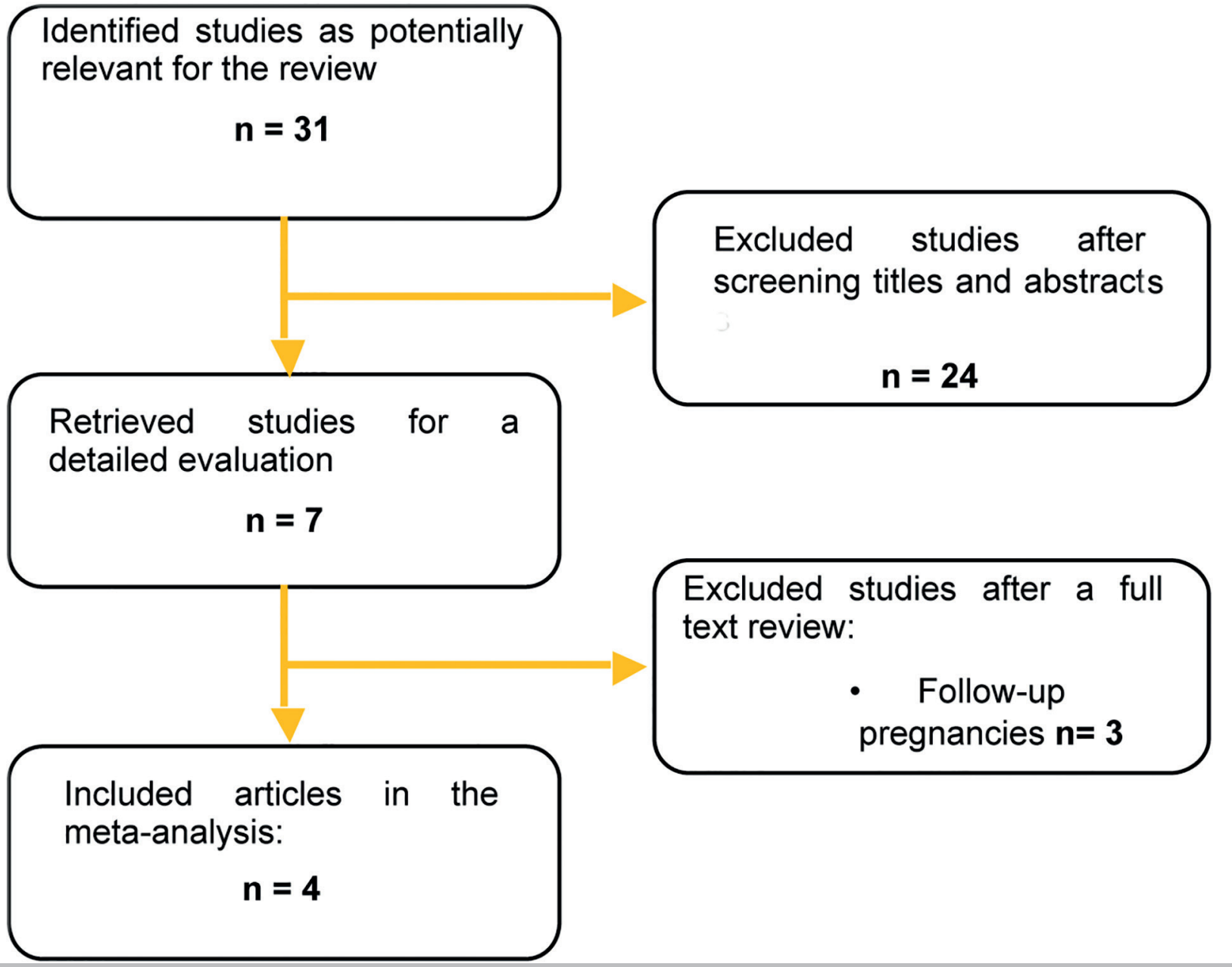

Figure 1. Systematic review flowchart.

(STATA Corp, EEUU). The results were displayed in a forest plot (Figure 2).

Heterogeneity between studies was assessed with Higgins' $\mathrm{I}^{2}$ and Cochran's $\mathrm{Q}$ test. Heterogeneity was considered to be significant when $p<0.01$ and $\mathrm{I}^{2}>30 \%$.

\section{RESULTS}

The initial search retrieved 31 studies. No duplicates were found. After screening for titles and abstracts, 24 studies were excluded for not meeting the inclusion criteria. Seven remained for full text revisions, but three included ongoing pregnancies and were therefore excluded. Four papers met the inclusion criteria and were included in the systematic review and meta-analysis (Figure 2 ).

The four studies included were published between 1999 and 2015 and covered a total of 2,664 women offered ART. The main findings are summarized in Table 1 . Two of the studies were carried out in Europe, one in Asia, and one in the United States. All were retrospective cohort studies.

The groups were comparable for age in the selected papers. Only two studies mentioned the nutritional status of the patients with a mean body mass index of $22 \pm 4 \mathrm{Kg} /$ $\mathrm{m}^{2}$ (Łukaszuk et al., 2015; Zhong et al., 2012); two included only euthyroid women and two did not consider that condition, although they excluded individuals with other autoimmune diseases.
The methods used to determine the presence of TAI differed, as did their titrations: electrochemiluminescence immunoassay (Łukaszuk et al., 2015), chemiluminescent microparticle immunoassay (Zhong et al., 2012), radioimmunoassay (Negro et al., 2007), and enzymelinked immunosorbent assay (Kutteh et al., 1999) (Table 1). In two studies the anti-Tg and anti-thyroid peroxidase antibodies levels were measured (Łukaszuk et al., 2015; Negro et al., 2007), while the other two only the level of anti-thyroid peroxidase antibodies was measured (Kutteh et al., 1999; Zhong et al., 2012).

Thirty-one miscarriages were observed in 210 clinical pregnancies of women with antithyroid antibodies; and 158 miscarriages were seen in 1,371 pregnancies without antithyroid antibodies. The meta-analysis failed to find an association between TAI and higher risk of reproductive loss, $\mathrm{RR}=0.94$ 95\% confidence interval: 0.71-1.24; $p=0.879$ (Figure 2).

The heterogeneity between studies was not significant $\left(p=0.879, \mathrm{I}^{2}=0.00 \%\right)$.

\section{DISCUSSION}

The purpose of this review was to determine whether pregnant individuals with TAI offered ART were at higher risk of having a miscarriage. After summarizing four studies including a total of 1,581 pregnancies after ART, no association was found between TAI and miscarriage. 
Study

ID

RR $(95 \% \mathrm{Cl})$

$\%$

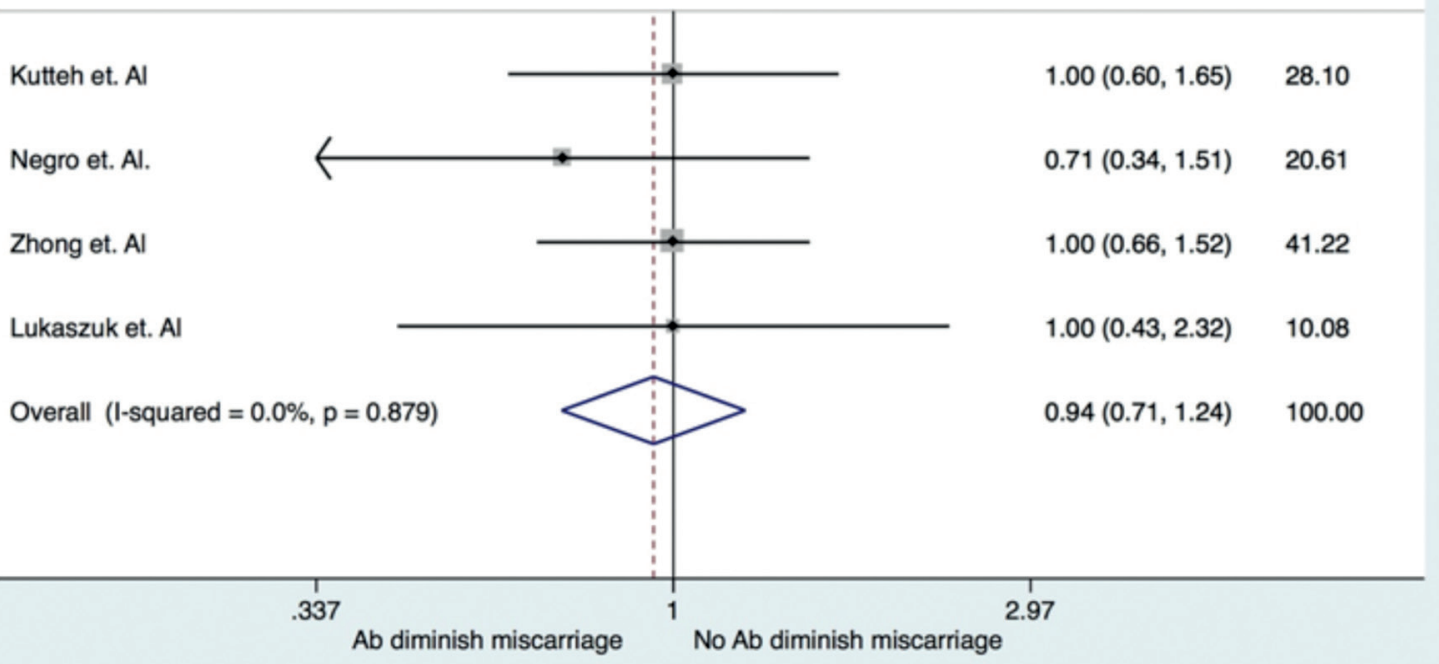

Figure 2. Forest plot: RR of miscarriage in TAI (+) patients undergoing ART.

Most of the studies included in this meta-analysis showed no statistically significant differences in fertility rate, number of embryos available, implantation rate or clinical pregnancy rates between the groups. These findings were consistent with the results reported by Karacan et al. (2013), in which implantation rates, spontaneous abortion rates, and pregnancy rates did not differ significantly between the groups with TAI and without TAI.

The strength of this study resided in the large number of analyzed patients, a total of 2,664 individuals given ART treatments. A weakness of the study was the fact that levels of thyroglobulin autoantibodies (anti-Tg) were not measured in every included study, which have been reported to be around $5 \%$ in patients suffering from infertility (Unuane et al., 2013). Another limitation was that only two studies included euthyroid patients; the other two did not consider this trait in their inclusion criteria, but had presence of other autoimmune diseases as a criterion for exclusion. Levothyroxine was not prescribed to every patient included. Since TSH levels and prescription of levothyroxine seem to be relevant for IVF outcomes, Poppe et al. (2004) looked into the thyroid function of females submitted to IVF procedures and the possible associations with reproductive outcomes, and reported a modified pattern in thyroid function during the first period of pregnancy after comparing the groups with and without TAI.

Most of the patients did not receive levothyroxine during pregnancy. The meta-analysis performed by Velkeniers et al. (2013) and the study by Negro et al. (2005) found that thyroxine supplementation for women with subclinical hypothyroidism and/or thyroid autoimmunity might improve clinical pregnancy outcomes in patients offered $A R T$, therefore such supplementation did not interfere with the outcomes described in our study.
The discrepancies between the results found in this study and in the papers written by Zhong et al. (2012) and Glinoer et al. (1991) may be explained by the mechanism of action of antithyroid antibodies; although this mechanism has not been completely described, it has been speculated that the anti-thyroid peroxidase antibodies can bind to the egg surface and/or embryo and interfere with fertilization and embryo development (Monteleone et al., 2011; Zhong et al., 2012). Our results, although contradictory at a first glance, seem to confirm this hypothesis: While TPOAb bound to the egg surface might prevent sperm cells from entering the egg during natural fertilization or IVF, it should not affect fertilization through intracytoplasmic sperm injection (ICSI), the method used in all patients in the included studies.

In conclusion, the presence of antithyroid antibodies was not associated with increased reproductive loss in patients submitted to ART treatments. It is our opinion that the presence of antithyroid antibodies should be considered as a secondary biomarker of autoimmune disease, rather than an actual cause of miscarriage in patients undergoing ART. Due to the small amount of evidence on the matter, the determination of TAI before the initiation of ART should be limited to research contexts.

\section{CONFLICT OF INTEREST}

The authors have no conflicts of interest to declare.

\section{Corresponding author:}

Juan Enrique Schwarze

Reproductive Medicine Unit

Clinica Monteblanco

Santiago, Chile

E-mail: jeschwarze@gmail.com 


\begin{tabular}{|c|c|c|c|c|}
\hline $\begin{array}{l}\text { Author, } \\
\text { year. } \\
\text { Country }\end{array}$ & Methods & TAI $(+)$ & TAI (-) & Conclusions \\
\hline $\begin{array}{l}\text { Lukaszuk } \\
\text { et al., } \\
2015 . \\
\text { China }\end{array}$ & $\begin{array}{l}\text { Retrospective Cohort study of } \\
\text { euthyroid women, age } 34-35 \text { years, } \\
\text { submitted to IVF/ICSI between April } \\
2010 \text { and April } 2012 \text {. } \\
\text { Population was divided in } 2 \text { groups: } \\
\text { patients with TPOAb+ }(n=114) \text { and } \\
\text { TPOAb- ( } n=495) \\
\text { Measurement of TPOAb by ECLIA. } \\
\text { Reference value: } 0-34 \mathrm{IU} / \mathrm{ml}\end{array}$ & $\begin{array}{l}\text { Clinical } \\
\text { Pregnancy: } \\
n=50 \\
\text { Miscarriage: } \\
n=3\end{array}$ & $\begin{array}{l}\text { Clinical } \\
\text { Pregnancy: } \\
n=235 \\
\text { Miscarriage: } \\
n=29\end{array}$ & $\begin{array}{l}\text { IVF patients undergoing ICSI with } \\
\text { TPOAb+ vs TPOAb- did not present } \\
\text { statistically significant differences } \\
\text { in fertilization, implantation, } \\
\text { pregnancy, and live newborn rates. } \\
\text { The presence of TPOAb did not } \\
\text { increase the risk of miscarriage ( } 6 \% \\
\text { vs. } 12.4 \%, p=0.29 \text { ) }\end{array}$ \\
\hline $\begin{array}{l}\text { Zhong } \\
\text { et al., } \\
2012 . \\
\text { Poland }\end{array}$ & $\begin{array}{l}\text { Retrospective cohort study of patients } \\
\text { (mean age }=32 \text { years) submitted to } \\
\text { IVF/ICSI between August } 2009 \text { and } \\
\text { August } 2010 \text {. } \\
\text { Population was divided in two groups: } \\
\text { patients with TAI [TPOAb+ and/or } \\
\text { anti-Tg+] }(n=90) \text { and without TAI } \\
(n=676) \\
\text { Measurement of TAI by CMIA: } \\
\text {-TPOAb }+\geq 561 \mathrm{UI} / \mathrm{ml} \\
\text {-anti-Tg+] } \geq 4.11 \mathrm{UI} / \mathrm{ml}\end{array}$ & $\begin{array}{l}\text { Clinical } \\
\text { Pregnancy: } \\
n=52 \\
\text { Miscarriage: } \\
n=14\end{array}$ & $\begin{array}{l}\text { Clinical } \\
\text { Pregnancy: } \\
n=458 \\
\text { Miscarriage: } \\
n=54\end{array}$ & $\begin{array}{l}\text { Fertilization implantation and } \\
\text { pregnancy rates after IVF-ET were } \\
\text { significantly lower (64.3\% vs. } \\
74.6 \%, p<0.001 ; 17.8 \% \text { vs. } 27.1 \% \text {, } \\
p<0.001 \text {; and } 33.3 \% \text { vs. } 46.7 \% \text {, } \\
p=0.002 \text {, respectively), whereas } \\
\text { miscarriage rates were significantly } \\
\text { higher ( } 26.9 \% \text { vs. } 11.8 \% \text { ) in } \\
\text { patients with TAI versus controls } \\
\text { (without TAI). }\end{array}$ \\
\hline $\begin{array}{l}\text { Negro } \\
\text { et al., } \\
2007 \\
\text { Italy }\end{array}$ & $\begin{array}{l}\text { Retrospective Cohort study of } \\
\text { euthyroid women aged } 20-35 \text { years, } \\
\text { carried out between January } 2000 \\
\text { and January } 2005 \text {. } \\
\text { A total of } 416 \text { patients were selected; } \\
42 \text { had TPOAb+ and } 374 \text { TPOAb-. } \\
\text { Measurement method of TPOAb by } \\
\text { RIA: } \\
\text {-TPOAb+ } \geq 100 \mathrm{Ku} / \mathrm{l}\end{array}$ & $\begin{array}{l}\text { Clinical } \\
\text { Pregnancy: } \\
n=21 \\
\text { Miscarriage: } \\
n=5\end{array}$ & $\begin{array}{l}\text { Clinical } \\
\text { Pregnancy: } \\
n=234 \\
\text { Miscarriage: } \\
n=27\end{array}$ & $\begin{array}{l}\text { In euthyroid patients, pregnancy } \\
\text { and delivery rates were not affected } \\
\text { by the presence of TPOAb. } \\
\text { In patients with TPOAb+, the } \\
\text { subgroup of patients that did not } \\
\text { achieve pregnancy had miscarriages } \\
\text { had higher TSH levels, but within } \\
\text { the normal range }(2.8 \mathrm{mUI} / \mathrm{ml} \text { ) vs. } \\
\text { patients that delivered (TSH } 1.06 \\
\mathrm{mUI} / \mathrm{ml}, p=0.032 \text { ) }\end{array}$ \\
\hline $\begin{array}{l}\text { Kutteh } \\
\text { et al., } \\
1999 \\
\text { USA }\end{array}$ & $\begin{array}{l}\text { Retrospective cohort study of women } \\
\text { aged } 35 \pm 4 \text { years offered IVF in } 3 \text { cen- } \\
\text { ters in the USA between April } 1996 \\
\text { and April } 1997 \text {. } \\
\text { From a total of } 873 \text { patients with ART, } \\
143 \text { women had TAI [TPOAb+ and/or } \\
\text { anti-Tg+]. } \\
\text { Results were compared to a control } \\
\text { group of } 200 \text { non-pregnant women of } \\
\text { childbearing age with no record of re- } \\
\text { productive problems } \\
\text { Measurement of AIT with ELISA: } \\
\text {-TPOAb+ } \geq 65 \mathrm{UI} / \mathrm{ml} \text {. } \\
\text {-anti-Tg+ } \geq 120 \mathrm{UI} / \mathrm{ml} \text {. }\end{array}$ & $\begin{array}{l}\text { Clinical } \\
\text { Pregnancy } \\
n=87 \\
\text { Miscarriage: } \\
n=9\end{array}$ & $\begin{array}{l}\text { Clinical } \\
\text { Pregnancy: } \\
n=444 \\
\text { Miscarriage: } \\
n=48\end{array}$ & $\begin{array}{l}\text { The presence of TAI was similar } \\
\text { between patients offered ART and } \\
\text { controls }(16.4 \% \text { vs. } 14.5 \% \text {, OR: } \\
1.16) \\
\text { No statistically significant differences } \\
\text { were found in delivery ( } 54.5 \% \\
\text { vs. } 54.2 \%, p=1.00) \text {, biochemical } \\
\text { miscarriage }(3.5 \% \text { vs. } 4.7 \% \text {, } \\
p=0.66), \text { clinical miscarriage }(6.3 \% \\
\text { vs. } 6.6 \%, p=1.00) \text {, and pregnancy } \\
\text { failure }(35.7 \% \text { vs. } 34.5 \%, p=0.85) \\
\text { rates between patients with and } \\
\text { without TAI. }\end{array}$ \\
\hline
\end{tabular}

\section{REFERENCES}

Abalovich M, Amino N, Barbour LA, Cobin RH, De Groot LJ, Glinoer D, Mandel SJ, Stagnaro-Green A. Management of thyroid dysfunction during pregnancy and postpartum: an Endocrine Society Clinical Practice Guideline. J Clin Endocrinol Metab. 2007;92:S147. PMID: 17948378 DOI: $10.1210 /$ jc. 2007-0141

Bussen S, Steck T. Thyroid autoantibodies in euthyroid nonpregnant women with recurrent spontaneous abortions. Hum Reprod. 1995;10:2938-40. PMID: 8747048 DOI: 10.1093/oxfordjournals. humrep.a135823

Chen L, Hu R. Thyroid autoimmunity and miscarriage: a meta-analysis. Clin Endocrinol (Oxf). 2011;74:513-9. PMID: 21198746 DOI: 10.1111/j.1365-2265.2010.03974.x
Davies T. Pathogenesis of Hashimoto's thyroiditis (chronic autoimmune thyroiditis). In: UpToDate, Post TW, ed. UpToDate, Waltham, MA. Available at: Available at: https://www.uptodate.com/contents/pathogenesis-ofhashimotos-thyroiditis-chronic-autoimmune-thyroiditis. Accessed: 16/12/2016

Glinoer D, Soto MF, Bourdoux $P$, Lejeune $B$, Delange $F$, Lemone M, Kinthaert J, Robijn C, Grun JP, de Nayer P. Pregnancy in patients with mild thyroid abnormalities: maternal and neonatal repercussions. J Clin Endocrinol Metab. 1991;73:4217. PMID: 1906897 DOI: $10.1210 /$ jcem-73-2-421

Karacan M, Alwaeely F, Cebi Z, Berberoglugil M, Batukan M, Ulug M, Arvas A, Camlıbel T. Effect of antithyroid antibodies on ICSI outcome in antiphospholipid antibody-negative euthyroid women. Reprod Biomed Online. 2013;27:37680. PMID: 23953066 DOI: 10.1016/j.rbmo.2013.07.002 
Kutteh WH, SchoolcraftWB, ScottRT Jr. Antithyroid antibodies do not affect pregnancy outcome in women undergoing assisted reproduction. Hum Reprod. 1999;14:2886-90. PMID: 10548642 DOI: 10.1093/humrep/14.11.2886

Łukaszuk K, Kunicki M, Kulwikowska P, Liss J, Pastuszek E, Jaszczołt M, Męczekalski B, Skowroński K. The impact of the presence of antithyroid antibodies on pregnancy outcome following intracytoplasmatic sperm injection-ICSI and embryo transfer in women with normal thyreotropine levels. J Endocrinol Invest. 2015;38:1335-43. PMID: 26280321 DOI: $10.1007 / s 40618-015-0377-5$

Männistö $T$, Vääräsmäki $M$, Pouta $A$, Hartikainen $A L$, Ruokonen A, Surcel HM, Bloigu A, Järvelin MR, SuvantoLuukkonen E. Perinatal outcome of children born to mothers with thyroid dysfunction or antibodies: a prospective population-based cohort study. J Clin Endocrinol Metab. 2009;94:772-9. PMID: 19106271 DOI: $10.1210 /$ jc. $2008-1520$

Monteleone P, Parrini D, Faviana P, Carletti E, Casarosa E, Uccelli A, Cela V, Genazzani AR, Artini PG. Female infertility related to thyroid autoimmunity: the ovarian follicle hypothesis. Am J Reprod Immunol. 2011;66:108-14. PMID: 21241400 DOI: 10.1111/j.1600-0897.2010.00961.x

Negro R, Mangieri T, Coppola L, Presicce G, Casavola EC, Gismondi R, Locorotondo G, Caroli P, Pezzarossa A, Dazzi $D$, Hassan $H$. Levothyroxine treatment in thyroid peroxidase antibody-positive women undergoing assisted reproduction technologies: a prospective study. Hum Reprod. 2005;20:1529-33. PMID: 15878930 DOI: 10.1093 /humrep/deh843

Negro R, Formoso G, Coppola L, Presicce G, Mangieri T, Pezzarossa A, Dazzi D. Euthyroid women with autoimmune disease undergoing assisted reproduction technologies: the role of autoimmunity and thyroid function. J Endocrinol Invest. 2007;30:3-8. PMID: 17318015 DOI: $10.1007 / B F 03347388$

Poppe K, Glinoer D, Tournaye H, Schiettecatte J, Devroey $P$, van Steirteghem $A$, Haentjens $P$, Velkeniers $B$. Impact of ovarian hyperstimulation on thyroid function in women with and without thyroid autoimmunity. J Clin Endocrinol Metab. 2004;89:3808-12. PMID: 15292309 DOI: $10.1210 /$ jc.2004-0105
Prummel MF, Wiersinga WM. Thyroid autoimmunity and miscarriage. Eur J Endocrinol. 2004;150:751-5. PMID: 15191343 DOI: 10.1530/eje.0.1500751

Stagnaro-Green A, Roman $\mathrm{SH}$, Cobin $\mathrm{RH}$, el-Harazy E, Alvarez-Marfany M, Davies TF. Detection of at-risk pregnancy by means of highly sensitive assays for thyroid autoantibodies. JAMA. 1990;264:1422-5. PMID: 2118190 DOI: $10.1001 /$ jama.1990.03450110068029

Stagnaro-Green A, Glinoer D. Thyroid autoimmunity and the risk of miscarriage. Best Pract Res Clin Endocrinol Metab. 2004;18:167-81. PMID: 15157834 DOI: $10.1016 /$ j.beem.2004.03.007

Thangaratinam S, Tan A, Knox E, Kilby MD, Franklyn J, Coomarasamy A. Association between thyroid autoantibodies and miscarriage and preterm birth: metaanalysis of evidence. BMJ. 2011;342:d2616. PMID: 21558126 DOI: $10.1136 / \mathrm{bmj} . \mathrm{d} 2616$

Unuane D, Velkeniers B, Anckaert E, Schiettecatte J, Tournaye $\mathrm{H}$, Haentjens $\mathrm{P}$, Poppe K. Thyroglobulin autoantibodies: is there any added value in the detection of thyroid autoimmunity in women consulting for fertility treatment? Thyroid. 2013;23:1022-8. PMID: 23405888 DOI: $10.1089 /$ thy.2012.0562

Velkeniers B, Van Meerhaeghe A, Poppe K, Unuane $D$, Tournaye $H$, Haentjens P. Levothyroxine treatment and pregnancy outcome in women with subclinical hypothyroidism undergoing assisted reproduction technologies: systematic review and meta-analysis of RCTs. Hum Reprod Update. 2013;19:251-8. PMID: 23327883 DOI: $10.1093 /$ humupd/dms052

Zhong YP, Ying Y, Wu HT, Zhou CQ, Xu YW, Wang Q, Li J, Shen XT, Li J. Relationship between antithyroid antibody and pregnancy outcome following in vitro fertilization and embryo transfer. Int J Med Sci. 2012;9:121-5. PMID: 22253557 DOI: $10.7150 /$ ijms.3467 